\title{
PENDAMPINGAN PENGELOLAAN PAJAK BAGI UMKM DI KOTA PALEMBANG
}

\author{
Muhammad Hidayat1), Lukluk Fuadah'2), Sri Maryati3), Nur Khamisah" ${ }^{4}$, \\ Ruth Samantha Hamzah ${ }^{5)}$
}

\author{
1)23344)5JJurusan Akuntansi, Universitas Sriwijaya \\ Jln. Raya Palembang Prabumulih KM.32 Ogan Ilir, Sumatera Selatan \\ Email : muhammadhidayat@fe.unsri.ac.id ${ }^{1}$, lukluk fuadah@unsri.ac.id ${ }^{2}$, maryatisri@fe.unsri.ac.id $^{3}$, \\ nurkhamisah08@fe.unsri.ac.id $^{4}$, ruth samantha@fe.unsri.ac.id $^{5)}$
}

\begin{abstract}
ABSTRAK
Kegiatan pengabdian kepada masyarakat telah kami laksanakan di Kota Palembang, Provinsi Sumatera Selatan dengan judul Pendampingan Pengelolaan Pajak Bagi UMKM di Kota Palembang, pesertanya meliputi wajib pajak pribadi dan wajib pajak badan dengan kategori UMKM yaitu wajib pajak pribadi atau wajib pajak badan yang mempunyai omset satu tahun kurang dari Rp4.800.000.000,- yang ada di Kota Palembang, baik itu yang ada di wilayah Ilir Timur, Ilir Barat maupun Seberang Ulu. Tujuan dari pengabdian ini adalah untuk menginformasikan dan membantu wajib pajak UMKM untuk mengenal maupun melaksanakan kewajiban perpajakan yang akan atau sedang mereka jalankan, sehingga diharapkan dapat meningkatkan kesadaran wajib pajak dan meningkatkan pendapatan negara. Metode pelaksanaan pengandian menggunakan metode presentasi dan pendampingan langsung di tempat usaha wajib pajak. Hasilnya dapat dilihat bahwa wajib pajak telah sadar akan kewajiban akan pelaporan pajak atas usaha yang telah mereka jalankan. Dimana ada wajib pajak yang baru mendaftarkan diri untuk mendapatkan NPWP dan wajib pajak yang akan mendaftarkan NPWPnya, dan sebagian besar kegiatan kami adalah untuk membantu menghitung dan melaporkan pajak yang harus dilaporkan oleh wajib pajak.
\end{abstract}

Kata kunci : Pajak, UMKM, Pendampingan, Penerimaan Negara

\section{PENDAHULUAN}

\subsection{Analisis Situasi}

Pemerintah Indonesia pada tahun 2019 menargetkan penerimaan pajak sebesar 1,786 Triliun Rupiah yang akan digunakan untuk membiayai pembangunan yang dilaksanakan. Target penerimaan pajak tersebut berasal dari wajib pajak yang menjalankan usahanya di Indonesia. Target penerimaan pajak tersebut akan tercapai apabila semua wajib pajak memberikan kontribusi nyata pembayaran pajaknya sesuai dengan amanat yang tercantum dalam undang-undang perpajakan. Dalam menentukan pembayaran pajak yang terhutang dibutuhkan pemahaman yang baik dalam pengelolaan dan penyusunan laporan keuangan perusahaan. selain itu, diperlukan juga pemahaman yang baik dalam bidang perpajakan sehingga pembayaran pajak yang dilakukan sesuai dengan peraturan yang berlaku.

Target penerimaan pajak yang terus meningkat dari tahun ke tahun menyebabkan pemerintah terus melakukan pembenahan dalam sector perpajakan. Perubahan peraturan perpajakan dan penggunaan teknologi informasi dalam bidang perpajakan diharapkan dapat mampu meningkatkan pendapatan dalam sector perpajakan. Namun penerapan peraturan dan penggunaan teknologi informasi tersebut masih belum mampu diikuti oleh wajib pajak yang masuk dalam kategori Usaha Mikro, Kecil dan Menengah. Keterbatasan SDM merupakan factor utama masih belum sampainya target, aturan dan fasilitas perpajakan yang diberikan oleh pemerintah kepada wajib pajak. Jumlah kategori usaha kecil yang ada di kota Palembang menurut BPS kota palembag pada tahun 2018 berjumlah 124 usaha kecil yang tersebar di 16 Kecamatan Kota Palembang, jumlah tersebut belum ditambah dengan usaha mikro dan menengah sehingga potensi penerimaan pajak dapat dilaksanakan apabila dapat dilakukan pendampingan pengelolaan pajak.

Pelaksana kegiatan pendampingan merupakan Dosen Fakultas Ekonomi Jurusan Akuntansi yang aktif dalam penelitian dan implementasi ilmu akuntansi dan perpajakan. Transfer pengetahuan merupakan salah satu yang harus dijalankan Dosen tidak hanya kepada mahasiswa namun juga 
kepada Masyarakat yang ada di wilayah kampus tersebut. Pelaksanaan kegiatan ini juga didukung dengan fasilitas tax center yang dimiliki oleh Fakultas Ekonomi, sehingga kegiatan pendampingan ini akan berjalan maksimal. Kota Palembang terdiri atas 16 Kecamatan yang mempunyai potensi pajak yang besar, mengingat banyaknya UMKM yang tersebar di Kota Palembang. Diharapkan dengan proses pendampingan ini akan banyak membantu UMKM yang ada di Kota Palembang

\subsection{Identifikasi dan Perumusan Masalah}

Permasalahan yang dihadapi oleh wajib pajak di kota Palembang adalah:

a. Wajib pajak UMKM masih banyak yang belum mengerahui aturan umum dan tata cara perpajakan, sehingga wajib pajak masih mengalami kendala mengenai kewajiban pajak yang harus mereka jalankan.

b. Terbatasnya petugas pajak di Kota Palembang menyebabkan tidak semua wajib pajak mendapatkan edukasi perpajakan yang memadai.

c. Masih ada resistensi di wajib pajak untuk mendatangai petugas pajak di daerah masing-masing

d. Pengelolaan keuangan yang masih minim menyebabkan potensi pajak yang seharusnya dibayarkan oleh wajib pajak tidak sesuai dengan peraturan yang berlaku.

e. Pemanfaatan teknologi dalam proses Self Assessment System perpajakan menyebabkan wajib pajak mengalami kesulitan dalam menyelesaikan kewajiban perpajakan mereka.

f. Target penerimaan pajak merupakan penerimaan utama dalam APBN sehingga diperlukan ekstensifikasi perpajakan kepada masyarakat sehingga penerimaan pajak dapat tercapai.

\subsection{Solusi Permasalahan}

Dalam hal menyelesaikan permasalahan yang dihadapi oleh wajib pajak diperlukan pendampingan yang komprehensif terhadap perpajakan wajib pajak sehingga kesadaran wajib pajak tersebut akan meningkat, dan diharapkan adanya peningkatan penerimaan dalam sektor perpajakan. Adapun kerangka pemecahan masalah adalah sebagai berikut :

\section{Bagan 1. Solusi Permasalahan}

\begin{tabular}{|c|c|c|c|}
\hline $\begin{array}{c}\text { Pendampingan } \\
\text { Pengelolaan } \\
\text { Perpajakan }\end{array} \longrightarrow \begin{array}{c}\text { Meningkatnya pemahaman wajib } \\
\text { pajak terhadap perpajakan }\end{array} \longrightarrow \begin{array}{c}\text { Meningkatnya Penerimaan } \\
\text { Pajak Negara }\end{array}$ \\
\hline
\end{tabular}

\section{METODE PELAKSANAAN PENGABDIAN}

\subsection{Metode Pelaksanaan Kegiatan}

Metode pelaksanaan pendampingan ini dilakukan dengan cara dua metode, yang pertama adalah dengan memberikan pelatihan perpajakan dan konsultasi, adapun pelatihan yang dilakukan akan berisikan tentang:

a. Sosialisasi aturan perpajakan bagi UMKM

b. Peritungan perpajakan bagi UMKM

c. Pelatihan penggunaan aplikasi perpajakan, ESPT dan Efaktur

d. Tanya Jawab Materi Pelatihan

Selain dengan metode pelatihan, kegiatan ini juga akan ada metode konseling, dimana tim akan menjadwalkan pertemuan yang telah disepakati dengan peserta pendampingan, sehingga penerapan pelatihan yang telah diberikan akan terserap secara maksimal.

\subsection{Evaluasi}

Evaluasi keberhasilan kegiatan pendampingan ini dintentukan oleh beberapa indikator, dimana indikator yang digunakan adalah

a. Wajib pajak mampu menghitung jumlah pajak yang terhutang atas transaksi yang dilakukan

b. Wajib pajak mampu membuat laporan pajak (SPT Pajak) untuk masa pajak setelah pelatihan dilaksanakan

Pendampingan ini dapat dinyatakan berhasil jika wajib pajak dapat menghitung, menyetor dan melaporkan kewajiban perpajakannya dengan baik. 


\subsection{Waktu dan Jadwal Kegiatan}

Jadwal kegiatan pendampingan pengelolaan perpajakan bagi wajib pajak UMKM adalah sebagai berikut :

Tabel 1. Jadwal Kegiatan

\begin{tabular}{|c|c|l|}
\hline Hari & Jenis Kegiatan & \multicolumn{1}{c|}{ Materi } \\
\hline Hari 1 & Pelatihan Perpajakan & $\begin{array}{l}\text { Penyusunan Laporan keuangan, perhitungan } \\
\text { perpajakan dan penggunaan aplikasi perpajakan }\end{array}$ \\
\hline $\begin{array}{c}\text { 1 Bulan } \\
\text { Setelah }\end{array}$ & Visitasi dan Konseling & Konseling mengenai kewajiban perpajakan \\
\hline $\begin{array}{c}\text { 1 bulan } \\
\text { setelah } \\
\text { peatihan }\end{array}$ & Pendampingan Pelaporan & \\
\hline
\end{tabular}

\subsection{Khalayak Sasaran}

Khalayak sasaran dari pengabdian ini adalah semua wajib pajak UMKM yang ada di Kota Palembang yang memiliki peredaran bruto tidak lebih dari 4,8 Miliar Rupiah dalam satu tahun pajak. Adapun peserta pendampingan pengelolaan pajak bagi umkm adalah sebagai berikut

Tabel 2. Khalayak Sasaran

\begin{tabular}{|r|l|l|l|l|}
\hline No & \multicolumn{1}{|c|}{ Nama Usaha } & \multicolumn{1}{|c|}{ Jenis WP } & \multicolumn{1}{c|}{ Jenis Usaha } & \multicolumn{1}{c|}{ Nama Peserta } \\
\hline 1 & Rita & Perorangan & Gas Elpiji & Rita \\
\hline 2 & PT. Safaat & Badan & Jasa Transportir & Tiara \\
\hline 3 & PT. Safaat & Badan & Jasa Transportir & Riana \\
\hline 4 & Liza & Perorangan & Jual Beli Makanan & Liza Hartini \\
\hline 5 & Liza & Perorangan & Jual Beli Makanan & Miftahul Jannah \\
\hline 6 & CV. Alina & Badan & Jasa Pengadaan Barang & Tarbiyatun Nadhiro \\
\hline 7 & CV. Alina & Badan & Jasa Pengadaan Barang & Ali Ibrahim \\
\hline 8 & CV. Sriwijaya Teknologi & Badan & Jasa TI & Ali Bardadi \\
\hline 9 & CV. Sriwijaya Teknologi & Badan & Jasa TI & Pita Rosemari \\
\hline 10 & Angga Primadeka & Perorangan & Penjual Makanan & Angga Primadeka \\
\hline 11 & PT. Enviro Jaya Global & Badan & Jasa Lingkungan & Yulia Fitri \\
\hline 12 & PT. Enviro Jaya Global & Badan & Jasa Lingkungan & Ali \\
\hline 13 & Rani Kartika Sari & Perorangan & Jasa Percetakan & Rani Kartika Sari \\
\hline 14 & CV. JJ Production & Badan & Percetakan & Hamzah \\
\hline 15 & Muhammad Nurdin & Perorangan & Jual Beli Sparepart & Muhammad Nurdin \\
\hline 16 & CV. Prima Teknik & Badan & Jual Beli Sparepart & Nyimas Yunia Soliha \\
\hline 17 & CV. Prima Teknik & Badan & Jual Beli Sparepart & Muttaqin \\
\hline 18 & Diaz Almalik & Perorangan & Perdagangan & Diaz Almalik \\
\hline 19 & PT. Kelvin Indotama & Badan & Jasa Transportasi & Kevin \\
\hline 20 & PT. Kelvin Indotama & Badan & Jasa Transportasi & Rio \\
\hline
\end{tabular}

\section{HASIL DAN PEMBAHASAN}

\subsection{Hasil}

Kegiatan pengabdian ini dilaksanakan pada tanggal 1 Nopember - 30 Nopember 2019. Kegiatan dilakukan dengan cara kunjungan langsung ke lokasi peserta pengabdian masyarakat atau di kantor pelayanan pajak di Kota Palembang. Pelaksanaan pengabdian dimulai dengan penjelasan mengenai peraturan-peraturan perpajakan untuk UMKM, setelah wajib pajak mengetahui mengenai kewajiban 
perpajakan, Tim pengabdian membuat janji untuk pelaksanaan lanjutan pengabdian untuk pelaporan perpajakan. Pelaksanaan pengabdian ini diikuti oleh 20 orang perwakilan dari wajib pajak pribadi dan wajib pajak badan. Adapun pelaksaan pendampingan pengelolaan pajak ini dapat dilihat pada gambar dibawah ini :
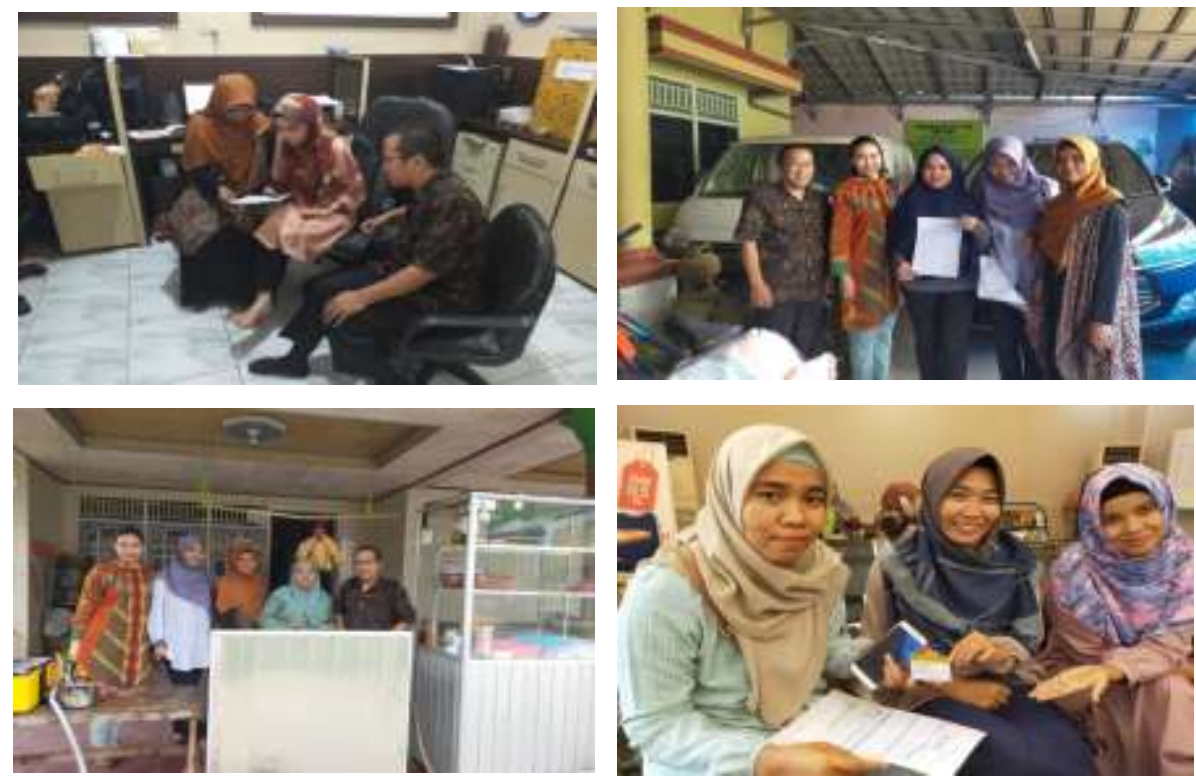

Gambar 1. Proses Pelaksanaan Pengabdian di Tempat Wajib Pajak

\subsection{Pembahasan}

Dari hasil pelaksanaan pengabdian diketahui bahwa banyak wajib pajak yang membutuhkan pendampingan pengelolaan pajak mereka. Wajib pajak butuh pendampingan dikarenakan mereka segan untuk berkonsultasi langsung dengan Account Representative dari Direktorat Jendral Pajak, hal ini disebabkan wajib pajak takut untuk mengungkapkan data perpajakan mereka kepada Direktorat Jendral Pajak.

Terdapat juga wajib pajak yang tergerak untuk memiliki NPWP setelah mendapatkan penjelasan dari tim pengabdian, dan beberapa wajib pajak merasa terbantu setelah dilakukan pendampingan dalam pengelolaan perpajakan mereka. Wajib pajak tersebut bersedia untuk melanjutkan program pendampingan hingga pelaporan tahunan 2019 di tahun 2020.

Pendampingan ini menghasilkan wajib pajak yang akan membuat Nomor Pokok Wajib pajak (NPWP), ada yang telah dibantu untuk membuat NPWP untuk usahanya, ada yang dibantu untuk pelaporan PPh Final, Pelaporan PPh Pasal 21 dan Pelaporan pajak Pertambahan Nilai. Adapun hasil atas pendampingan ini berupa NPWP baru dan laporan pajak diantaranya dapat dilihat pada gambar dibawah ini
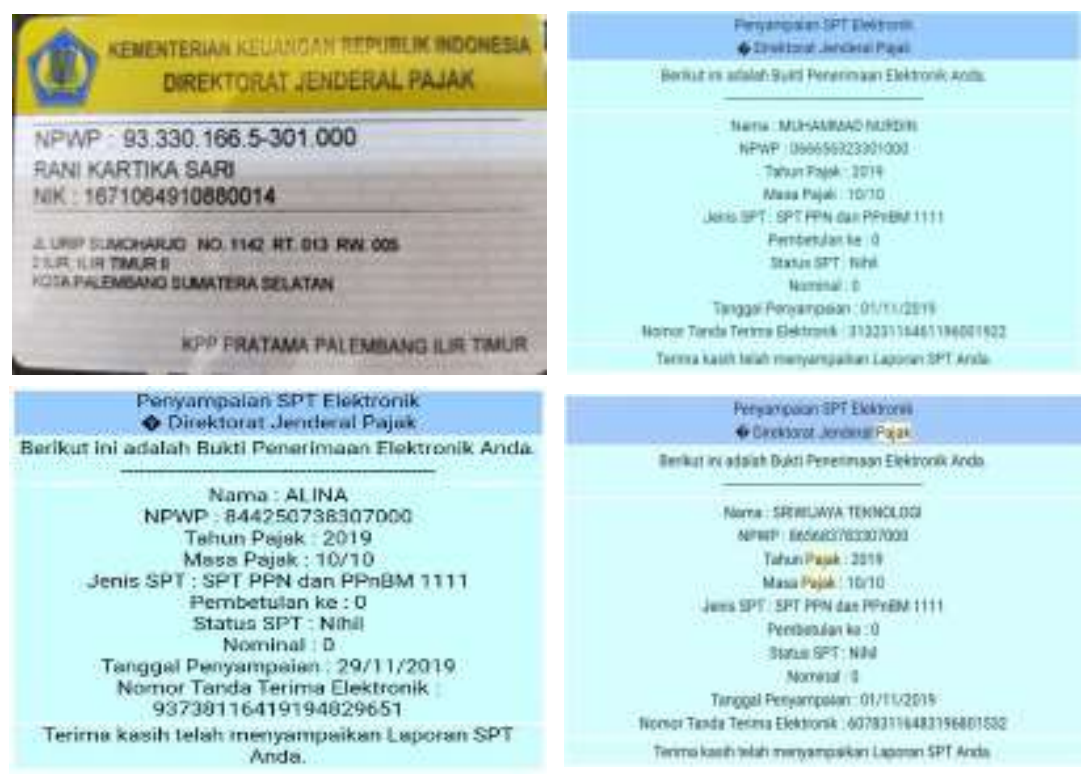
Gambar 2. Output Laporan Pajak

Wajib pajak yang ikut dalam pengabdian ini berjanji untuk terus melakukan pelaporan kewajiban pajak yang harus mereka lakukan. Dari hasil pengabdian ini membuka wawasan bagi tim bahwa dibutuhkannya sukarelawan untuk mendampingi wajib pajak dalam pengelolaan pajaknya.

\section{KESIMPULAN}

Kegiatan pengabdian pendampingan pengelolaan pajak bagi UMKM di Kota Palembang yang dilaksanakan selama bulan Nopember 2019 dapat disimpulkan sebagai berikut:

1. selama pelaksanaan pengabdian diketahui bahwa terdapat wajib pajak yang baru mengetahui peraturan wajib pajak bagi UMKM, dan wajib pajak yang terbantu dengan adanya pendampingan pengelolaan pajak.

2. Berdasarkan evaluasi yang dihasilkan, hasil pengabdian ini meningkatkan kesadaran wajib pajak untuk mematuhi kewajiban perpajakannya. Peningkatan kesadaran ini diharapkan dapat meningkatkan penerimaan negara.

3. Berdasarkan hasil pengabdian, tim memberikan saran kepada wajib pajak untuk secara konsisten memenuhi kepatuhan perpajakannya. Dan bagi pihak universitas untuk terus dapat mendukung program pendampingan pengelolaan perpajakan bagi UMKM di Palembang dan dapat diperluas di daerah yang lain.

\section{UCAPAN TERIMA KASIH}

Ucapan terima kasih kami berikan kepada Kementerian Riset Teknologi dan Pendidikan Tinggi, Fakultas Ekonomi, Universitas Sriwijaya yang telah membantu terlaksananya pengabdian ini melalui bantuan dana dengan Nomor: 0021/UN9/SB3.LP2M.PM/2019, tanggal 23 Agustus 2019.

\section{DAFTAR PUSTAKA}

Undang-Undang Republik IndonesiaNomor 28 Tahun 2007. Perubahan Ketiga Atas Undang-Undang Nomor 6 Tahun 1982 Tentang Ketentuan Umum dan Tata Cara Perpajakan.

Mardiasmo. 2016. Perpajakan. Edisi 18. Penerbit Andi

Hidayat, Muhammad. 2013. Modul Praktikum Perpajakan. Fasilkom Universitas Sriwijaya

Peraturan Pemerintah Nomor 46 Tahun 2013 Tentang Pajak Penghasilan Atas Penghasilan Dari Usaha

Yang Diterima Atau Diterima Oleh Wajib Pajak Yang Memiliki Peredaran Bruto Tertentu

Resmi, Siti. 2017. Perpajakan: Teori dan Kasus. Edisi 10. Penerbit Salemba Empat 